\title{
Pedagogy of CLE and CLE as pedagogy: An interview with Ved Kumari
}

\author{
Latika Vashist $^{1}$
}

Accepted: 23 December 2020 / Published online: 20 January 2021

(c) O.P. Jindal Global University (JGU) 2021

\begin{abstract}
In this conversation with Ved Kumari, Professor and Former Dean, Faculty of Law, University of Delhi, we navigate through different conceptions and practices of Clinical Legal Education (CLE), practical and ethical challenges in the implementation of CLE, and the importance of critical theory and jurisprudence to achieve the pedagogical goals of CLE. Drawing on her experience as a feminist clinical law professor, she critically approaches the twin goals of CLE - social justice and professional legal skills — on the one hand, and flags affective concerns which arise in live-client and community-based clinics, on the other. The conversation centres on the importance of the values of sustainability, professionalism, empathy, and critical self-reflection in conceptualisation and incorporation of CLE in the legal curriculum.
\end{abstract}

Keywords Live-client clinics $\cdot$ Social justice $\cdot$ Practical skills $\cdot$ Trauma $\cdot$ Clinical pedagogy $\cdot$ Empathy $\cdot$ Reflection

\section{Introduction}

After the Delhi Gang Rape, in 2012, when popular sentiments against the accused, including the juvenile accused, called for severe punishment and change in the existing laws, including the juvenile justice law, Professor Ved Kumari wrote to the Verma Committee, imploring it to take a nuanced approach in its recommendations. 'After lot of emotional and intellectual turmoil', she said, 'I have learnt to balance

\footnotetext{
* Latika Vashist

latikavashist@gmail.com

1 Indian Law Institute, New Delhi, India
} 
the two apparently conflicting rights and believe that while I stand by all rape victims and survivors, I do not believe that women's rights are better protected by punishing children for offences they commit against women or anybody else.' ${ }^{1}$ Public rage and fury had announced the discursive impossibility of compassionate justice. At that moment, when collective imagination demanded the death penalty for all accused, including the juvenile, she was one of the very few voices who continued to display a courageous compassion towards the juvenile whom the media reports had wrongly reported to be the most brutal. Asking us to focus on the child, she wrote:

While condemning the ghastly brutality of the rape of Nirbhaya, I want to focus on the child involved in the offence. Let our outrage at the absence of safe spaces for women, not blind us to the absence of care to children too. This boy was all of 13 years when he left home. Why did he leave? What was his home like? What happened to him in the last five years? What all has been responsible for turning him into this beast? Why juvenile justice system in place in our country did not reach out to him and prevented him from being what he has become today $?^{2}$

Justice lies in the interstices of disciplinary boundaries and conflicting rights claims, hidden in the cracks of lived experiences which are flattened to fit the legal template by the time they reach policy-making corridors and courtrooms. A legal mind is trained to know how blameworthy is the offender, but the question of how he arrived at blameworthiness often remains muted. Why did he leave? What was his home like? What happened to him in the last five years? What all has been responsible for turning him into this 'beast'? For Ved Kumari, who teaches and researches at the intersection of feminism and juvenile justice, Clinical Legal Education (CLE) — learning the law by doing, seeing, experiencing, feeling — offers possibilities of working through and responding to such repressed questions of legal education.

Professor Ved Kumari has been engaged with the workings of legal aid clinics at the Faculty of Law, University of Delhi, for more than four decades, first as a student, then as a 'non-clinical' lecturer, and now, since 1996, as a clinical law teacher. The Faculty of Law was the pioneer institution in introducing and nurturing CLE through legal aid clinics. The legal aid bureau, set up in 1970 to provide legal services to the impoverished, had evolved into the Students Legal Services Clinic. ${ }^{3}$ Many teachers of the faculty - Lotika Sarkar, NRM Menon, N Mysore, Upendra Baxi, BB Pande, Poonam Saxena, Nomita Agarwal - spearheaded various legal aid initiatives and programmes. However, clinical projects in the Law Faculty functioned 'intermittently', dependent largely on 'the labour of love of teachers and

\footnotetext{
1 'Submissions to Justice Verma Committee by Ved Kumari, Professor of Law, Faculty of Law, University of Delhi and former Chairperson, Delhi Judicial Academy'. https://feministlawarchives.pldindia.org/ wp-content/uploads/submissions-by-ved-kumari.pdf. Accessed 8 August 2020.

2 Ibid.

${ }^{3}$ NRM Menon, 'Students Legal Services Clinic: The Delhi Experience' in NRM Menon (ed), Legal Aid and Legal Education: A Challenge and an Opportunity: Essays on Clinical education for the Law Student in a Service Setting (University of Delhi 1974).
} 
students'. ${ }^{4}$ We know very little of this past as '[n]o formal records have been maintained by the Faculty and the Centres about the innumerable legal aid initiative taken by its teachers. ${ }^{5}$ Ved Kumari, as the second-generation feminist clinical law professor at the Law Faculty, inherited this uneven, undocumented legacy of CLE which survived mostly in anecdotes. Therefore, for her, 'sustainability' and 'professionalism' have become the key values for effectively imparting CLE in the law schools.

Despite institutionalisation in the legal curriculum - first through Bar Council of India (BCI) directives in 1997, mandating four clinical courses in the LLB curriculum, ${ }^{6}$ and then through the 2011 regulations of the National Legal Services Authority (NALSA) requiring law schools to set up legal aid clinics as part of CLE ${ }^{7}-$ CLE remains on the fringes of mainstream legal education as well as pedagogies in both public and private universities. In her teaching, writing, and research, Ved Kumari focuses on wide-ranging reasons - conceptual as well as systemic, institutional as well as individualistic - for such othering of CLE in legal education in India. Unimpressed by grand policy designs on paper, celebrated and romanticised in the legal academy, Ved Kumari's focus, as a true clinician, has been on honest actualisation and effective implementation of the policy recommendations across law schools. For her, there is no substitute for rigour and nuance in social justice-based and empathy-driven clinical theory or practice.

In 2002, five years after the BCI prescribed compulsory clinical courses, she pointed out the conceptual as well as practical conundrums with the courses (which

\footnotetext{
${ }^{4}$ Ved Kumari, 'Legal Aid Clinics in Law Schools: Ensuring Sustainability and Professionalism' in Raman Mittal and KV Sreemithun (eds), Legal Aid: Catalyst for Social Change (Satyam Law International 2012) 95.

5 Ibid. 96. One exception is the monograph on the Beggars Project of the Legal Aid Clinic of the Campus Law Centre, where professors and students of the Campus Law Centre represented indigent persons who were arrested under the Bombay Prevention of Begging Act, 1959, as extended to Delhi in June 1960. The Legal Aid Clinic, under the supervision of Professor BB Pande, then Director of the Legal Services Programme, Faculty of Law, put together this monograph titled Beggary Prevention Laws: Rhetoric and Reality (2004). The Beggars Project, which was started in 1976, continued till the retirement of Professor BB Pande in 2005.

6 In 1997, the BCI mandated all law schools to incorporate four compulsory clinical courses in the law school curriculum. These papers are: (a) Drafting, Pleading, and Conveyance; $(b)$ Professional Ethics and Professional Accounting System; $(c)$ Alternate Dispute Resolution; and $(d)$ Moot Court Exercise and Internship. These courses are required to be conducted by senior legal practitioners (practising lawyers and retired judges) through simulation exercises, case studies, and other practical work. See 'Compulsory Clinical Courses' in Bar Council of India Education Rules 2008, Part IV, Rules of Legal Education (2008) 24-25. http://www.barcouncilofindia.org/wp-content/uploads/2010/05/BCIRulesPartIV.pdf. Accessed 18 July 2020. In 2002, the Law Commission of India's report stated that clinical legal education should be compulsory. See Law Commission of India, 184th Report on the Legal Education \& Professional Training and Proposals for Amendments to the Advocates Act, 1961 and the University Grants Commission Act, 1956 (2002) 95-96. http://lawcommissionofindia.nic.in/reports/184threport-PartI.pdf. Accessed 20 July 2020. Now law schools are also required to have at least one 'community-based legal aid clinic'. Bar Council of India, Guidelines for the Inspection of Universities/Institutions by the Bar Council of India (2010) 36. http://www.barcouncilofindia.org/wp-content/uploads/2010/06/Inspection -Manual2010.pdf. Accessed 18 July 2012.

7 National Legal Services Authority (Legal Services Clinics) Regulations (2011), Regulation 24. https ://nalsa.gov.in/acts-rules/regulations/national-legal-services-authority-legal-services-clinics-regulation s-2011. Accessed 6 August 2020.
} 
persist to this date), wanting as they were from the perspective of not only social justice goals of legal education but also professional lawyering skills. ${ }^{8}$ These courses in their existing form, she wrote, do little to ensure active participation of students in the learning of law. They posed many administrative challenges for all law schools and departments (like training of teachers in clinical methods, teacher-student ratio, effective supervision techniques, and evaluation criteria), relegated the social justice component to the background, and said little about balancing the workload of both students and clinical teachers in community-based projects. These concerns are as relevant today as they were 20 years ago.

Now when all law schools are urged to set up legal aid clinics as part of the existing CLE courses, ${ }^{9}$ she has emphasised upon the 'huge social and professional responsibility of working for the needy' for 'legal aid provided to the poor should not become poor legal aid'. ${ }^{10}$ To this end, she insists, law school clinics must: $(a)$ train students in practical skills (client interviewing and counselling, communication, maintaining files, keeping records, maintaining logbook and writing journal, legal and social research methods, legal writing, ADR mechanisms, professional ethics); (b) collaborate with legal services institutions; and (c) assist legal aid lawyers. ${ }^{11}$

Besides the challenge of securing the twin goals of CLE - social justice and professional legal skills - there are also pressing concerns regarding ethical as well as affective issues which arise in different contexts of CLE. If not carefully planned, designed, and taught, CLE (especially live-client clinics and communitybased projects) can end up becoming a top-down 'rescue mission'. CLE thus necessarily needs to be supplemented by a critical theory of clinical praxis - dismantling all illusions of theory/practice binary that circulate in the naive articulations of clinical practice ${ }^{12}$ - which focuses and reflects on modes of clinical intervention, relationships between clients and students, affective site of clinic, emotional impact on students and clinicians who witness acute deprivation, suffering, and injustice in their work. In the absence of such theorisation and affective training in the ethics of 'doing', CLE can end up reinforcing dominant narratives about suffering and injustice, as well as social, political, and cultural hierarchies which it seeks to challenge and displace.

These concerns have been central to Ved Kumari's clinical pedagogy. Wary of over-zealous and callous community-based interventions, she notes:

\footnotetext{
8 Ved Kumari, 'Clinical Legal Education: Issues of Justice' (2002) 24 Delhi Law Review 78, 81.

${ }^{9}$ Kumari, 'Legal Aid Clinics in Law Schools' (n 4) 98-102.

${ }^{10}$ Ibid. 104.

11 Ibid. 104-110.

${ }^{12}$ Critical legal theories - critical race theory, gender studies, Dalit studies, adivasi/tribal studies - give an entry point in clinical classrooms for initiating discussions on concepts of difference, subordination, power, agency, which are crucial for evolving client-centred lawyering practices, as also systemic critiques of legal and political institutions which form the backdrop to lawyer-client relationships. For a discussion on how critical theory can be integrated in the clinical curriculum, especially live-client clinics, and how it facilitates the larger pedagogical aims of CLE, see Margaret E Johnson, 'An Experiment in Integrating Critical Theory and Clinical Education' (2005) 13(1) American University Journal of Gender, Social Policy \& the Law 161.
} 
It is of utmost importance to remember that all community projects leave an impact on the people whose lives they touch.... Since the people whose life these projects touch are usually deprived it is the responsibility of the project directors to ensure that the students' learning projects should not result in greater disillusionment or harassment to the clients. Hence ... [all] activities in the field need to be preceeded by rigorous classroom training. ${ }^{13}$

Clinical legal education thus requires a model of not merely social justice lawyering but also empathic lawyering, ${ }^{14}$ where suffering is not appropriated by the empathiser to secure a pre-determined goal. The clinic needs to evolve client-centred listening practices where students learn not to displace clients' narratives 'by silencing the voices of clients and applying false assumptions about client dependency and powerlessness to their interpretation of client stories'. ${ }^{15}$ Sarah Buhler, whose work foregrounds affective dimensions of the suffering encounter in clinical settings, argues that 'a critical 'pedagogy of suffering' - one that seeks to understand suffering in its historical and social context and to critically examine problematic responses to social suffering - can be an important aspect of clinical law teaching and practice. ${ }^{16}$ This will require "cultivating practices of "critical witnessing" and "critical listening" as part of a "critical emotional praxis" "17 which will "encourage students to understand emotional responses to their clients as potential resources for analysis and fuel for passionate responses to suffering, but always subject to a critical analysis and a search for underlying assumptions'. ${ }^{18}$ Simply put, the clinic ought to emerge as the site of affective engagement with law.

There is an urgent need for clinic to deal with the questions of injustice and acknowledge - contrary to the long-standing claims of dispassionate legal discipline — 'emotions and affect as politically and indeed legally relevant, and as a resource for further reflection and action'. ${ }^{19}$ Recently, clinical law teachers have initiated discussions around pedagogies of 'trauma-informed lawyering' 20 in clinics where students are encouraged and trained to recognise and understand trauma in the clients and the effects of possible 'vicarious trauma' ${ }^{21}$ on themselves or those

\footnotetext{
13 Kumari, 'Clinical Legal Education' (n 8) 85.

14 Peter Margulies, 'Re-framing Empathy in Clinical Legal Education' (1998-1999) 5 Clinical Law Review 605.

15 Sarah Buhler, 'Painful Injustices: Encountering Social Suffering in Clinical Legal Education' (2013)

19 Clinical Law Review 405, 410.

16 Ibid. 411.

17 Ibid. 417.

18 Ibid. 423. Buhler cautions that "compassionate or empathetic emotional responses to suffering can serve to sustain the very power relations that create the conditions for suffering in the first place, and can also obscure the role of the empathizer in ongoing conditions of injustice.' Ibid. 414.

19 Ibid. 422.

20 Sarah Katz and Deeya Haldar, 'The Pedagogy of Trauma-Informed Lawyering' (2016) 22 Clinical Law Review 359.

21 'Vicarious traumatization refers to harmful changes that occur in professionals' views of themselves, others, and the world, as a result of exposure to the graphic or traumatic experiences of their clients.' Some of the symptoms of vicarious trauma are 'denial of clients' trauma, over-identification with clients, no time and energy for oneself, feelings of great vulnerability, experiencing insignificant daily events as threatening, feelings of alienation, social withdrawal, disconnection from loved ones, loss of confi-
} 
who are representing the traumatised clients. The pedagogy of trauma-informed lawyering, it is believed, would strengthen CLE's existing goals of social justice, client-centred lawyering, and acquisition of practical lawyering skills. It will equip students to recognise situations where the legal system reaches its limits in responding to a trauma-affected client. And also allow students to learn essential values and professional skills of understanding clients' perspectives, emotions, the possible effects of trauma on clients' decisions, choices, and actions.

Some of these discussions around 'pedagogies of CLE' and 'CLE as pedagogy' were a part of the following conversation with Professor Ved Kumari. Home-bound in the corona virus enforced lockdown, we met virtually through the Zoom application. I transcribed the recordings and, while editing, took the liberty of removing repetitive parts and insignificant details. I also restructured some of the questions and responses to give the free-flowing dialogue the form of an 'interview'. References and footnotes were added in the end for the benefit of the readers.

\section{Interview}

Latika Vashist (LV): The context of this conversation is the Special Issue of the Jindal Global Law Review on the theme of Clinical Legal Education. But I want to start by asking you about the other two areas of your research - feminism ${ }^{22}$ and juvenile law. ${ }^{23}$ How have they come to inform your work as a clinical legal educator? How have these three traditionally distinct areas of legal specialisation intersected and converged to create your worldview as a feminist clinician?

Ved Kumari (VK): I think one cannot understand any subject — whether it is juvenile justice, feminism, or any other course — without going to the field and witnessing the ground realities. Legal practice is not only about knowledge that can be gathered passively from law books. In fact, whichever legal profession one chooses - advocacy, judicial work, policy-making, or legislative work — one needs to primarily understand how law impacts people's lives. We cannot grasp the law, the real workings of law only by reading law books or by only reading what other people are saying and their theorisations.

I have come to understand both juvenile justice and gender through experiential learning. I think my learning in juvenile justice is grounded because my LLM

\footnotetext{
Footnote 21 (continued)

dence that good is still possible in the world, generalized despair and hopelessness, loss of feeling secure, increased sensitivity to violence, cynicism, feeling disillusioned by humanity, disrupted frame of reference, changes in identity, world view, and spirituality, diminished self-capacities, impaired ego resources, and alterations in sensory experiences.' Ibid. 368-369.

22 See Ved Kumari, 'Gender Analysis of Indian Penal Code' in Amita Dhanda and Archana Parashar (eds), Engendering Law: Essays in Honour of Lotika Sarkar (Eastern Book Company 1999) 139-160; Ved Kumari and Ravinder Barn, 'Sentencing in Rape Cases: A Critical Appraisal of Judicial Decisions in India' (2017) 59(1) Journal of Indian Law Institute 1.

23 Ved Kumari, The Juvenile Justice (Care and Protection of Children) Act 2015: Critical Analysis (Lexis Nexis 2017); Ved Kumari, Juvenile Justice System in India: From Welfare to Rights (Oxford University Press 2011).
} 
dissertation on this subject was based on field work. My first exposure to the 'field' was during the bachelor's degree (LLB) course at the Delhi Law Faculty. ${ }^{24}$ There was a legal aid clinic running with the Child Welfare Board and as students, we were asked to visit. Later, while pursuing my master's degree (LLM), I did a theoretical course on juvenile delinquency with Professor Lotika Sarkar, and my field work for the LLM dissertation was on juvenile institutions. At that time, law students rarely did field work but that experience was crucial for my understanding of juvenile laws. It really grounded me. It gave me insights into the realities of children's lives, and their voices. It gave me the necessary connection between law in books and law on the ground. Without this connection, without meeting real people, without dealing with actual scenarios of injustice, one cannot really understand the law. And I strongly feel that CLE provides that connection.

Similarly with gender, my learning has been experiential. We keep saying 'personal is political'; this is not just a slogan, we need to understand its import. Gender too remains an abstract theoretical construct unless one makes one's personal experiences central: how my personal life has been impacted, how discrimination we read about in law books is happening in our personal life but we never recognise it as such. So learning the law is about making connections with real lives, of others as well as one's own. And CLE provides that opportunity. Even in a simulated course in CLE, even if it is not a live-client clinic, students get to learn what they can possibly never learn from books. For instance, how patterns of communication work. Communication is not law and cannot be learnt from law books, but nevertheless it is a very important part of courtroom proceedings both for the judges and the lawyers. The students who have done simulated activities in the clinical classroom, when they go to courts, things become more alive. When they learn by doing, they can see similarities as well as differences in the classroom simulation exercises and the actual courtroom practices. And this remains true for all law subjects. Even if one wants to do, say, bankruptcy in litigation, one needs to know what kind of forms are to be filled, what kind of practices are prevalent. So learning about the law is one part, but if you want to learn the impact of law or how to apply the law, then you have to see the real situations.

LV: So you are saying that the 'personal' in 'personal is political' needs close attention in feminism and in law, and CLE offers possibilities of getting thick descriptions in which the complexities and contradictions of the personal will emerge. I want to ask you something about the objectives and approaches of CLE. From the very beginning CLE has always been conceptualised with the dual objectives of imparting professional legal skills to the students and advancing social justice. While this is true globally, ${ }^{25}$ in India, this connection between CLE and social

\footnotetext{
${ }^{24}$ The legal aid clinic of the Faculty of Law, University of Delhi, was set up in 1970 through the efforts of Professors Lotika Sarkar, NRM Menon, and N Mysore. Over the years, the legal aid clinic conducted many projects and programmes including, but not limited to, the Beggars Project and legal literacy programmes.

25 See Frank S Bloch (ed), The Global Clinical Movement: Educating Lawyers for Social Justice (Oxford University Press 2010).
} 
justice has been foundational to the clinical movement. ${ }^{26}$ But over time, especially with the Bar Council of India's (BCI's) conception of clinical courses making inroads into the legal curriculum, CLE overwhelmingly came to focus on practical skills that are required for lawyers. You were very critical of the BCI's model and you had emphasised upon 'mainstreaming of legal aid clinics ... by incorporating them in the LL.B. curricula. ${ }^{27}$ Many other clinical teachers have also critiqued this skewed approach of BCI and have insisted on a social justice-based clinical curriculum. ${ }^{28}$ While continuing to emphasise upon the social justice component, you have shifted from your previous position on the integration of legal aid clinics in the existing LLB curriculum. ${ }^{29}$ Can you elaborate on how you now conceive of compulsory legal aid clinics as part of law school curriculum?

VK: To understand this, we need to know that there are two approaches of looking at CLE: CLE which focuses on imparting practical and professional skills to students and CLE which mandates the involvement of students to extend legal support to the community. To me, both of these are equally important and compulsory at the professional level. Let me explain what do I mean by professional level. In Delhi University, we had a prison project with the legal services authority. So when we used to organise prison visits, some 250 -odd students would volunteer for it. I was completely opposed to such field trips for the students. I wanted that first students should be given some basic skills, some basic knowledge of the prison system, the issues with the prison administration, etc. So I had insisted that first of all students should be introduced to the theory of prison administration and prisoners' rights and only then they should be allowed to visit the prison. But my other colleagues were not in agreement; they thought that 'exposure' itself is sufficient. Well, exposure is important but even then unless we de-brief them after the visit, students return without really learning anything. I remember some students came back from the prison and told me that 'they [prison inmates] look very much like us', that 'the prison was very green and they were playing badminton', that 'it did not feel like they were incarcerated'. So these students, in that brief visit for 'exposure', did not get any

\footnotetext{
${ }^{26}$ In 1973, the Expert Committee on Legal Aid of the Ministry of Law and Justice recommended the introduction of clinical legal education with a focus on poverty issues into law schools. In 1977, the Committee on National Juridicare stated that law schools should establish legal aid clinics that can facilitate structural changes through grassroots involvement. In 1981, the Committee for Implementing Legal Aid Schemes called for the establishment of legal aid clinics. Curriculum Development Committees in 1988 and 2000 also sought to improve the overall quality of legal education and make law school curricula responsive to the needs of the people. See Government of India, Ministry of Law, Justice and Company Affairs, Report of the Expert Committee on Legal Aid: Processual Justice to the People (1973); Government of India, Ministry of Law, Justice and Company Affairs, Report on National Juridicare: Equal Justice-Social Justice (1977); Government of India, Ministry of Law, Justice and Company Affairs, Department of Legal Affairs, Report of Committee for Implementing Legal Aid Services (1981).

${ }^{27}$ Kumari, 'Clinical Legal Education' (n 8) 82.

${ }^{28}$ See Frank S Bloch and MRK Prasad, 'Institutionalizing a Social Justice Mission for Clinical Legal Education: Cross-national Currents from India and the United States' (2006) 13 Clinical Law Review 165.

${ }^{29}$ Kumari, 'Legal Aid Clinics in Law Schools' (n 4).
} 
sense of the confinement or the loss of liberty that the prison stands for. I don't find any use of such 'sensitisation' or 'exposure'.

The students had to be given some kind of orientation before the visit. But with such a large group (250 students), it is very difficult, unless we take out extensive time for this exercise, split them into smaller groups of 10-15, make them talk and reflect on their experiences. Without this, it can be damaging even for the students. We had another clinic on plea bargaining where, once again, many students volunteered, many more than the number of undertrials who had to be interviewed. Four-five students were involved in interviewing a single prisoner. But on the date of hearing none of the students who did the interview was present to tell the court what was agreed upon! This damages the whole idea in its entirety. The prison visits are not just meant for the students, they are also for the prisoner. So we need to make sure that the visit is preceded by a training for five days, which will also weed out those students who are looking at it like a tour or who are going to see how a prison looks like. When it comes to students' learning and you are dealing with real clients, you have to ensure as the teacher supervisor that there is continuity, and individualised supervision is being given to every student. Unless we are ready to do this, I do not recommend a live-client clinic at all.

Then we have to go the other way round, frame simulation-based clinical courses and give them practical skills. Focus on practical skills, simulation exercises, interviewing skills, communication, how to make an argument, and then give them an exposure, ask them to visit and make notes, compare what they learnt in classroom with what they discovered in the courtroom. But if anyone is planning to fuse the two together, i.e., practical legal skills as well as legal aid through a course or a project, then there has to be a very strict vigil on what the students are doing on the ground. It is not about sending 50 students to the field and putting a tick mark on the check-list. So we have to be very thoughtful when we choose to have a live-client clinic. And, to precisely answer your question, I do not subscribe to the division between practical skills approach and service to the community. Both, as I said, are equally important but both need to be done in a thoroughly professional manner. ${ }^{30}$ Another thing is that the legal aid clinics should not be seen in terms of charity work. I have a strong objection to the charity model of CLE.

LV: Yes, we do notice how, in some settings, CLE ends up assuming a charity framework. I want to thank you for emphasising and clarifying this. I want to come back to this issue but before that, can we go back to the question of social justice and its centrality to CLE?

VK: On the question of social justice, I do not think we can teach any law paper - clinical or otherwise - without the social justice component. For me, the question of social justice should not be confined only to CLE, even though it is crucial for CLE. Social justice has to be integrated in all our thinking of the law generally. Whether any specific law that you are learning will and ought to promote social justice is the central question for legal education. For any group of people, who all

${ }^{30}$ See, for details, Kumari, 'Legal Aid Clinics in Law Schools' (n 4). 
will be negatively impacted or are on the receiving end of the law, all these issues are a part of social justice training which every law course should be oriented towards.

When we talk about CLE and social justice, let us be very clear that it is not about going to the clinic and serving the people of the community. That is no doubt important but this alone offers a very limited understanding of social justice. Our perspective has to be oriented towards social justice in a way that it is incorporated in every aspect of the law that we study in the university. We need to ask questions looking at all laws critically from this perspective. For example, why does contract law fail to take cognisance of woman's work? How do we look at taxation law from the perspective of social justice? So, the question of justice has to be central to the teaching and learning of all law. Professor Upendra Baxi has asked us many times: how many times do law teachers use the word 'justice' in class? This is a question for all law teachers, and not just clinicians to carefully think about.

LV: The idea that social justice is not exclusive to CLE is something which is so obvious, yet forgotten in law school teaching. Social justice is also connected to institutional practices and in the context of CLE specifically, various law schools have developed their own institutional practices to implement the compulsory clinical courses, and have also set up community-based clinics. ${ }^{31}$ What, according to you, are the pre-requisites for running a clinical course effectively?

VK: First of all, as I have previously said, when we think of introducing CLE or offering a clinical course, we need to be clear whether we are talking about practical skills or community-based live-client clinics. If we are talking only about practical skills, these can be taught even in the absence of a live-client clinic. A live-client clinic is a different setting as it focuses both on practical skills as well as community engagement. Live-client clinics can be instituted either as compulsory clinical courses for which students are graded, or solely for providing legal aid to the community in which students' participation is done on a voluntary basis. But we need to remember that when we do CLE as a part of a compulsory paper which will be evaluated, it has a completely different connotation and a different objective from a legal clinic where students participate voluntarily. The sustainability of such a clinic is far more as compared to a semester-long compulsory course which BCI mandates.

If one chooses to have a live-client clinic as an evaluated course, then to start with, maintaining teacher-student ratio is crucial. There should be a professional person, a lawyer, team-teaching this course along with the clinical teacher. This is because in India, full-time teachers are not allowed to practise law in the courts. ${ }^{32}$

\footnotetext{
31 The clinical courses have been designed and implemented through legal aid services like lok adalats, paralegal services in correctional homes, free legal aid cells where students offer legal services and also carry out research and undertake advocacy through public interest litigations. For details see Bloch and Prasad, 'Institutionalizing a Social Justice Mission' (n 28) 200-206.

32 Bar Council of India Rules, Part VI (Rules Governing Advocates), Chapter II (Standards of Professional Conduct and Etiquette), Rule 49. http://www.barcouncilofindia.org/wp-content/uploads/2010/05/ BCIRulesPartVonwards.pdf. Accessed 20 July 2012. Rule 49 reads: An advocate shall not be a full-time salaried employee of any person, government, firm, corporation, or concern, so long as he continues to practise, and shall, on taking up any such employment, intimate the fact to the Bar Council on whose roll his name appears and shall thereupon cease to practise as an advocate so long as he continues in such employment.
} 
So we are aware that full-time teachers rarely have mastery over the skills that make a good lawyer. Law teachers also do not have any training in the clinical methods. They are not given any training about how to teach a theoretical course, forget about a clinical course! So, at best, law teachers know what the law is, and how to find the law but do they know how to do effective communication? They are never made to undergo any training about effective communication which is crucial for any lawyer. Even other aspects of the practice of law, for example, filling of basic legal documents like the bail bond, are not introduced in the curriculum. We have the compulsory Drafting, Pleading, and Conveyance (DPC) course which tells the students some basics, but are we telling the students what kind of documents are to be filed for bail surety? Who can be surety, where should the property be, where the signatures are to be put? These are all important issues when we talk about the bail law. But in law schools, when we teach the law on bail, we only tend to focus on issues like classification of offences as bailable/non-bailable, judges' discretion in granting bail, cases around it, and that is all. Do we tell the students how to actually get a person released on bail, what documents are required? None of this is a part of the course on criminal procedure, which is generally taught as a purely theory paper. In my view, when we are teaching CrPC (Criminal Procedure Code, 1973), we should necessarily be able to show the students the legal documents that are a part of the workings of legal processes. For instance, students should be made to see how a charge-sheet looks, how a charge-sheet is read, what aspects should one look at to build one's case, what are the supplementary documents, all of this should be a part of the CrPC course.

Similarly, when we teach substantive criminal law, say the law on murder, we cannot just stop at telling the students about concerned legal provisions. We must point out how this gender-neutral law is actually gendered by referring to the difference in patterns of killing by men and women, that women are more among the victims when murders take place in the private sphere, or how loss of self-control due to sudden and grave provocation is an exclusive male and not human reaction. We need to necessarily teach them how to build a case, how to prepare witnesses, how to prepare arguments. Some of this can be done through simulation exercises, while in some areas simulation may not be as satisfactory as a live-client clinic. But the broad point that I am making is that the practical knowledge about the legal processes should be integrated with the theory papers. And this is CLE for me. We don't need real clients for this; we just need the case files. The practical skills can be learned through such incorporation of CLE in main papers. Students should be made to learn the law not just from reading law books but from reading and analysing actual living legal documents which lawyers and judges work with.

There is another issue which needs to be addressed when we are conceiving of CLE courses. CLE cannot solely focus on practical skills required for lawyers only. This is how BCI has imagined CLE but we know that not all law students want to become practising lawyers. Many of them want to become judges, some want to do legal journalism, some want to become law researchers. So there are diverse career possibilities. Therefore, to imagine that CLE is only about making professional lawyers, and focusing solely on practical skills which lawyers need to the exclusion of other career possibilities in law, is a bad starting point from my perspective. 
LV: So you are suggesting that CLE, like gender, should be integrated in all our courses. Rather than just a select few separate clinical courses.

VK: Precisely. Like gender, it should inform our teaching of all law subjects. But even today criminal law, family law continue to be taught without adopting the lens of gender. And it is believed that gender should be done separately in a separate course. This kind of thinking is very problematic. CLE needs to be integrated in every paper. We cannot continue with this division between the theory paper and its practical side. Every paper has to have the practical component. Therefore, all law courses need to be restructured so that practical aspects of every specific paper are integrated within it. For instance, when we teach company law, the students should be asked to form a company and by the end of the course students should have done everything that is needed from forming to dissolving the company.

LV: Can you share a little about how and when did you first get introduced to CLE?

VK: It was in 1995. I was already teaching as a lecturer at Delhi University and we were expected to do two compulsory courses for promotion as per the University Grants Commission (UGC) mandate. So I enrolled in a three-week refresher course on CLE at National Law School University India (NLSUI), Bangalore. I realised that the faculty members conducting the course were outstanding. As our resource persons, we had Professor Frank Bloch, Professor Jane Schukoske, Professor Clark Cunningham, and Professor Ken Gallant from the USA, Professor Rodger Burridge from the UK, and Professor Merlene Le Brun from Australia. Everything was taught through participation and simulation. It was indeed a life-altering experience for me as a teacher. I was totally enamoured by the novel teaching methodology which ensured learning by doing. It totally changed the way I taught the substantive law courses. I started applying the clinical methods — role play, simulation — in my teaching of criminal law. Today, after all these years, integration of clinical methods is crucial in my teaching of substantive law papers. So for me CLE is not about a separate course taught by a few select teachers. CLE is about adopting clinical methods in all our teaching and of incorporating the practical component in the theoretical papers, changing the focus from teaching to 'learning by doing', making students active participants in the process.

LV: Yes, I see the compelling need for holistic incorporation of CLE in legal pedagogy, as opposed to its isolated existence in law schools. I am also very keen to know your views on how CLE is made compulsory, but legal philosophy including theory of justice and feminist jurisprudence have been made optional papers in the LLB programme. ${ }^{33}$ Doesn't this reveal a lack of foresight in curriculum drafting? Isn't a deep understanding of jurisprudence, critical legal theory, and feminist legal theory essential to advance the objectives of CLE? ${ }^{34}$

\footnotetext{
${ }^{33}$ Bar Council of India, Rules of Legal Education, 2019. http://www.barcouncilofindia.org/wp-conte nt/uploads/2010/05/BCI-65-2020-LE-All-VC-Registrar-Reg-Draft-Rule-of-Legal-Educaiton-2019.pdf. Accessed 20 December 2020.

${ }^{34}$ For a discussion of the importance of critical theory for CLE, see Johnson, 'An Experiment in Integrating Critical Theory and Clinical Education' (n 12).
} 
VK: Absolutely. Suppose, as a clinic, you want to file a public interest litigation (PIL). Can it be done without a fair understanding of concepts of justice, rights, equality, or gender? How can you build up a case for a PIL? I don't think you can. Especially at the appellate level, it is not possible to conceive of advocacy without a firm grounding in jurisprudence, critical theory, feminist theory. ${ }^{35}$ But unfortunately BCI sees no connection between jurisprudence and advocacy. They seem to think that jurisprudence and legal theory are about some abstract ideas and therefore jurisprudence is of interest only for academicians but has no relevance for litigating lawyers and judges. This understanding of jurisprudence is itself extremely impoverished and lacks clarity. This is the reason it has been made an optional paper. But then again, when I say jurisprudence is absolutely essential and it should be a compulsory course, I also think we need to learn how to teach the jurisprudence. For the longest time, jurisprudence has not been taught the way it should be. Words and expressions like 'social engineering', 'pure theory of law', etc. are thrown around but not concretised through examples from real life. I remember my teachers of jurisprudence - Professor Upendra Baxi and Professor Mool Chand Sharma - who made the subject so alive for us by grounding the concepts and frameworks in the everyday, taking examples from newspapers, from the happenings around us, so that we could make the connections between abstract ideas and our lives.

LV: So it is not just institutionalisation but the optimism of will on the part of individual teachers that is equally important ${ }^{36}$ Here, I want to ask a connected question of how CLE courses are often considered as individual-driven and a lot of clinical initiatives, therefore, grow and wither away with the one particular faculty member. One can really count the number of law teachers who were trained in CLE and set up legal aid clinics in their respective institutions. Many of those initiatives subsided as these teacher retired or left the institutions. What steps can be taken to institutionalise CLE in a way that its sustainability is not dependent on individual faculty members?

VK: I can tell you what we did in Law Centre I. When I came back from my sabbatical in 2006, we organised a three-day workshop in teaching methods. That workshop was not just on clinical courses, instead we focused on making active student participation a crucial aspect of teaching methods for all courses. When CLE became compulsory, we had to involve all the teachers. We made the senior teachers who had training in CLE team-teach with junior faculty members and empower the latter and make them ready for the upcoming semester. Simultaneously, I did

\footnotetext{
${ }^{35}$ Delhi Law Faculty teachers have developed a rigorous course on feminist jurisprudence, with a detailed reading list, accessible at http://lawfaculty.du.ac.in/files/course_material/Old_Course_Material/ Content\%20LB-4031\%20-\%20GENDER\%20JUSTICE\%20AND\%20Feminist\%20Jurisprudence\%20Ful 1\%20Material\%20January\%202017.pdf. Accessed 20 December 2020.

${ }^{36}$ Here one may recall Amita Dhanda's energising argument about the power and responsibility of the singular - the individual law teacher - in transforming and enriching the structures and cultures of the legal academy. See Amita Dhanda, 'The Power of One: The Law Teacher in the Academy' in Amita Dhanda and Archana Parashar (eds), Decolonisation of Legal Knowledge (Routledge 2009) 261.
} 
teaching workshops with new teachers on teaching methods, ${ }^{37}$ as well as trainings on mediation, mock-trial, moot-court, client interviewing. ${ }^{38}$ We do these trainings every year because a CLE course cannot be satisfactorily conducted by teachers unless they are trained in clinical teaching methods. So we need to train the teachers to teach, otherwise you will get a lecture on what is good communication, or how to conduct a good interview. Teachers have to be taught how to do these things, only then will they be able to train the students. The senior teachers have to be taken on board and brought on ground. We cannot just leave it on the junior teachers. We also have to recognise that CLE courses are really work-intensive for both teachers and students. It is really time-consuming to create simulation problems, write role plays, prepare students for it, hold individual oral exams for all students, de-brief them after every simulation exercise. A lot of the work goes way beyond designated class hours. Besides this, in clinical courses the mathematics of the class also needs to be taught to the teachers - how to make groups of students for different exercises, how many problems should be assigned — as also the logistics of conducting the simulation activities. So we need to pay attention to all these aspects when we think of institutionalising CLE. At least, this is what we have been doing at the Law Faculty.

LV: You have been closely involved in Law Faculty's clinical programmes for more than two decades now. During this period you must have also witnessed the developments in CLE in other legal institutions. Do you see any differences in the way CLE is conceived and implemented in public universities as opposed to private universities/law schools? In as much as public-private institutional distinctions have no bearing on the conceptualisation of CLE per se, I am asking this question tentatively because the public-private division in Indian higher educational institutions has almost turned itself into a class distinction. Does that have an impact on the form, substance, focus, and eventual results of the clinical programmes in these spaces?

VK: I have not taught at any private university or even at National Law Schools so I am not in a position to comment on their clinical programmes. But yes, when it comes to high fee institutions, I know that in these elite spaces, some of their students, who are on fellowships, are not integrated into the mainstream campus life. There are various differences like rural-urban, English-speaking and non-English speaking, that persist. So if their own students remain on the margins, then I shudder to think about people who are socially and economically marginalised. I really don't know. But again, since I have not been closely involved with them, I cannot comment on their CLE programmes. But one thing has really been of serious concern to me. In many conferences and programmes, when people from elite legal institutions presented their data on clinical programmes, I was not convinced with their orientation or methodology. On probing a little, one finds that proper case files are not maintained, there is no serious supervision, etc. So there are a lot of charts and tall

\footnotetext{
${ }^{37}$ Faculty Development Programme on Teaching Methods, Faculty of Law, University of Delhi (14-20 March 2017).

38 Teachers' Trainings on Mediation, Negotiation, Case Analyses, Mock Trial, Faculty of Law, University of Delhi (September 2016-February 2017).
} 
claims, but I have not really got convincing responses from even the senior faculty of these institutions as far as the situation on the ground is concerned: the sustainability, follow-up with the community, and de-briefing of students.

There is another difference which, I believe, is important. Public institutions have students from diverse social and economic backgrounds. Some students have never seen a village and there are those who had not seen a big city before coming to the Law Faculty. Because of this wide variation in the classroom demography, students also learn from each other's experiences, they can check each other, something which is not possible in a homogeneous setting. Also, a lot of students have faced experiences of extreme deprivation in their own lives and they can relate to the people on the ground. I am obviously not claiming that at Law Faculty we have everything in order. I find our students also are not making the best use of the clinic. They sit outside, do clerical work of maintaining diaries when the real learning is taking place inside the clinic where they can learn so much from the ongoing client counselling session.

So a lot of improvement is required in all universities. But broadly, if CLE has been adopted as an institutional policy, we need to ask: how committed are these law schools to the goals of social justice in all aspects? Are these institutions instituting CLE and running clinics merely to fulfil the BCI requirements, or actually to meet the goals of social justice and professional legal education? What is their conception of law? What is the place of empathy in their conception of law? Are they really committed to the learning, teaching, and practising of law from the perspective of justice?

LV: In 2011, NALSA had directed the District Legal Services Authority (DLSA) to establish one legal clinic for a village or for a cluster of villages. ${ }^{39}$ Today many law schools are working in rural areas, extending legal aid and other paralegal support to the communities. ${ }^{40}$ However, the distinct focus on the 'rural' is, unfortunately, tied up with existing power hierarchies and stereotypical assumptions about rural and urban spaces, their requirements, the kind of legal support they need, by whom, etc. To take one example, the Draft Report of the Curriculum Development Committee, 2010, proposed the creation of 'Institutions with Differential Capacity' in its recognition of and response to the varied needs of rural India. It sought to design 'programs for both urban and rural Universities... Law Schools suitable for Trial courts lawyers would necessarily be low investment oriented institution but would require high skills to match the needs of the trial courts', since the Committee problematically assumed that the 'students passing out of rural Universities will join

\footnotetext{
39 National Legal Services Authority (Legal Services Clinics) Regulations (2011), Regulation 3. Regulation 23 provides: 'Law students may adopt a village for legal aid camps. - (1) Law students of the law colleges or law universities may adopt a village, especially in the remote rural areas and organise legal aid camps in association with the legal services clinic or Village Legal Care and Support System Care established under these regulations.'

40 See Ajay Pandey, 'Experimenting with Clinical Legal Education to Address the Disconnect between the Larger Promise of Law and Its Grassroots Reality in India' (2011) 26(1) Maryland Journal of International Law 135; Jane Schukoske and Latika Vashist, 'Achieving Socially Relevant Legal Education through Rural Legal Aid Clinics' in Mittal and Sreemithun, Legal Aid (n 4).
} 
trial court litigation. ${ }^{41}$ How do you see the renewed interest in the rural communities and their legal requirements? What should the clinicians not do in their engagement with the rural poor communities and while responding to their legal needs?

VK: I am reminded of an incident during my tenure at the Delhi Judicial Academy. ${ }^{42}$ We had reformulated the judicial training programme for the newly recruited judges who are required to undertake one year compulsory training at the Academy before joining service. We made village immersion a mandatory part of this training, ${ }^{43}$ where the trainees were required to spend one week in a village, mapping the village, interacting with the people, etc. After the first immersion programme, some of the trainee judicial officers told me that they did not find any gender discrimination in the village. Now, what does one make of this? Clearly, they were sent to the field without any orientation, without any understanding of how discrimination operates, without any insights to recognise discrimination. I wonder what kind of sensitisation would such a field work lead to. Also, when we organise such field visits, we should make our objectives very transparent to the community. The immersion was a short-duration sensitisation programme for the judges to give them firsthand exposure. The trainees were not supposed to make any interventions in the village. We had told them that they should make it clear at the very beginning that they were visiting the village to learn and not to help them in any way. In this case, the village community started expecting that the visiting officials from Delhi would do something to address their problems. The officers did end up holding a meeting with the local administration to brief them about the problems faced by the community. Hence, any field intervention creates expectations in the community even when the purpose is only learning for the students. They need to be trained properly so that they are equipped to handle the range of issues that will emerge beyond their brief.

Therefore, merely setting up a clinical programme in the village does not make sense. We need to be careful and thoughtful in this regard. I have seen how casually students end up taking such visits. They are not briefed about what they should do - starting from how they should introduce themselves to how they should dress up - and what they should not do. We cannot go and make promises which cannot be kept. It cannot be a random one-day trip. Necessarily, we need to make sure that there is follow-up. Unless we ensure this, students will not really learn anything and perhaps would only come back with their stereotypical ideas intact.

Specifically with regard to the broad policy of taking CLE to the rural areas, I have my reservations. At the heart of this policy is the hidden notion that rural areas are backward and need to be reformed through legal interventions. First of all, not everything is wrong with the villages. And second, injustice is present not just in rural areas. There is injustice all around us. So the law school clinic should be in the

\footnotetext{
41 See Draft Report of the Curriculum Development Committee (2010) 8. http://www.barcouncilofind ia.org/wp-content/uploads/2011/08/cdc-report-web.pdf. Accessed 20 July 2020.

42 Ved Kumari was the Chairperson of the Delhi Judicial Academy from July 2009 to July 2011.

43 Village Immersion Programme for officers of the Delhi Judicial Service in collaboration with District Administration, Kanpur (2010).
} 
neighbourhood. There are so many slums in the urban areas, do slum dwellers have enough legal support? The skewed sex ratio in cities shows that perhaps gender clinics are more urgently required in the cities than the villages. The on-site construction workers need support, law students should be working with them. There is no need to go to anywhere far if the objective of the clinic is to address and respond to injustices.

LV: I think you have touched on a very important aspect which exposes our complicity in structural violence. Our failure to acknowledge injustice in our vicinity, in our neighbourhoods, in our institutions, and in our homes is possibly the most fundamental feminist concern: of seeing the violence in/of intimate settings. I wish to bring in a related issue of legal education's lack of engagement with the question of emotions, either in the theory or the practice of law. ${ }^{44}$ Clinic surely is that space in a law school where it is impossible to ignore emotions and their impact on legal practice as well as practitioners. Sarah Buhler writes about evolving a critical 'pedagogy of suffering' in clinical contexts where the law students hear and witness stories of trauma and suffering and are required to respond to them: 'a pedagogy that views human suffering as a signifier of larger political and systemic injustice and that encourages lawyers and law students to engage in critical, attentive, and politicized "witnessing" and responses to suffering. ${ }^{45}$ How do you conceive of the suffering encounter in the clinical settings? How are students emotionally equipped to process and deal with trauma that they may experience during the course of their work?

VK: Law schools have never really addressed the question of trauma and suffering. When I was doing my field work on juvenile correctional institutions, I was shaken with one particular incident which continued to haunt me for a very long time. I had prepared a questionnaire for the respondents, the children living in these institutions. Generally I used to talk to them and write their responses on the questionnaire in my own hand. A girl who was about 11 years old, and was living in the institution from the age of 4 , told me that she wanted to fill it by herself. So she wrote the answers but in the end penned a long note addressed to me, saying how she felt I was her mother and that she could not bear to live without me, etc. I was completely shaken. I didn't know what to do, how to respond, how to process this. During my visits, I had told the children that I was a researcher and I was working to get my degree. So, according to me, I had made it clear that I was not there to help them. But then the field throws unexpected challenges at you. No one had really talked to me about the emotional impact the research could have on me (and also on the participants).

In sociology and social work, the field visit is followed by a 'recovery programme' to allow the researchers to come to terms with their difficult experiences. We necessarily need to provide support of psychological counselling to the students. I remember when we had gone to Bhuj in 2001 after the earthquake, witnessing such

\footnotetext{
44 On this theme, see Caroline Maughan and Paul Maharg (eds), Affect and Legal Education: Emotion in Learning and Teaching the Law (Routledge 2017).

45 Buhler, 'Painful Injustices' (n 15) 408.
} 
vast devastation had a huge impact on everyone. Students had never seen so much suffering and they needed to be given psychological support. At that time, Jamia Millia Islamia's Professor Bharati Sharma was working on the ground and she told me that they were holding psychological counselling for the students in the evening. So yes, we need to take up the neglected question of suffering and trauma. In my work with the judges, I came to realise that even they need psychological support - imagine hearing stories of violence and trauma every day. So at all levels we need to address this huge gap that exists within law.

At another level, the question is about our responses to others' suffering. How do we deal with suffering around us? How, for instance, do we deal with poverty around us? At red lights, when small children come begging, how do we respond? Generally it is by ignoring them, not looking at them, as if they are not there. So we survive by ignoring suffering or worse, by creating stereotypical images of the poor (that they are lazy, they don't want to work, they enjoy begging, etc.). The other response is one of charity where the other person becomes an object of our pity. Both these responses are flawed and co-equally disrespectful of the other, making it imperative for the legal discipline to create and design curriculums and programmes which cultivate sensitivity and empathy for the other.

$\mathbf{L V}$ : I think this is an extremely important issue of psychic difficulty in dealing with the suffering other. Taking this point forward, I want to bring on board the issue of the clinic itself as a site of power. Law clinic too can end up replicating the power hierarchies through dominant emotional reactions towards the 'other'. On the one hand, legal education's emphasis on objective and dispassionate determination of truth results in the creation of lawyering practices that tend to wipe off all emotions from clients' narrative in order to get to the 'relevant' facts and information which can fit the templates of law. On the other hand, clinicians/students sentimentalise the issues at hand, dangerously slipping into what you earlier called the charity/saviour mode. In both cases - of indifference as well as charity - the clients' voices are suppressed. Can you please share your views in this regard? Specifically, how can we inaugurate an ethical praxis within law school clinics which is premised on respect for the other?

VK: I think we need to start with classroom interactions. How do teachers interact with the students? Are we sensitive enough towards the students? I find the classroom interactions very hierarchical and patriarchal. Often we believe ourselves to be repositories of all knowledge and students to be empty vessels who just need to be filled with the knowledge, information, and our own notions of right and wrong. How many times do we try to find out what students are thinking? I think respecting the other needs to be practised first in the law classroom, which will then percolate to other areas of law.

Many times a lot of harm is done even when things are done with noble intentions because we end up assuming that we know what is best for others. I recall how in Andhra Pradesh, under a housing project, pukka (permanent) houses were constructed for the tribal population but newly built houses kept lying vacant. The tribals refused to live in them because, it was later learnt, the toilet was built within the same premises. No one had consulted them before the construction and designing. This happens because people from cities, studying and teaching in higher learning institutions, develop this false sense of superiority that they possess all knowledge and they have answers and solutions to all issues. In their zeal for doing something good, the whole 
exercise was done without any reflection or sensitivity towards the tribal preferences. So unless our education is focused on reflection, ${ }^{46}$ which makes us sensitive towards others' worldview, we cannot really achieve the goals of legal education.

Again, I am reminded of something Professor Upendra Baxi says, that when we teach a law, we should keep a track of three things: who will be benefited by it, who all will be required to change their behaviour, and who is asking for the changes to be brought? As teachers we need to pose these questions to ourselves. How often do we interrogate our own choices of courses, and topics? From whose perspective do we teach a particular subject? For instance, when taxation is taught, is it taught from the perspective of the tax-payer or the government? Is our focus on the income tax or, say, the tax on goods that we buy for our basic needs? These enquiries will tell us if we are teaching tax law from the perspective of those who have a lot of income or the impoverished. Focusing only on income tax, and leaving out the vast terrain of indirect taxes means that our focus is primarily on those who fall in the taxable income bracket, and not on the daily wage earners who are also tax-payers. Similarly, in the constitutional law course, how much time is devoted to fundamental rights and how much time is given to directive principles and fundamental duties? The overwhelming focus on fundamental rights shows that we are actually teaching the law from the perspective of those who are capable of holding fundamental rights. ${ }^{47}$ So we need to recognise the class, caste, and gender bias in our choices of teaching. What we teach, what we don't teach is a political choice. Again, it is about restructuring legal education (and not just CLE) in a way that we recognise class, caste, and gender prejudices in our thinking and actions. It is about envisioning legal pedagogies which seek to cultivate empathy as well as respect for others' desires and needs.

LV: This is a point that is emphasised by you throughout this interview: empathy and self-reflection in legal education. On that note, I want to thank you for your time. In your vision of CLE, there is both rigour and compassion. Even as you talked about radical rewriting of the legal curriculum which transcends the binary of theoretical and practical, you also showed us how we can start by making changes in our teaching materials and methods. I am sure that this conversation will motivate many of us, who either have 'practice aversion' or have been 'reluctant clinicians', to engage with clinical methods in classroom teaching as well as research. More importantly, I hope that we start a serious conversation about empathic legal education sustained by a 'critical emotional praxis'. Thank you so much once again.

Publisher's Note Springer Nature remains neutral with regard to jurisdictional claims in published maps and institutional affiliations.

\footnotetext{
46 'Reflexivity' is a basic concept in feminist research methodology. For Sandra Harding, 'a robust gender-sensitive reflexivity practice' entails that 'the class, race, culture and gender assumptions, beliefs and behaviors of the researcher her/himself must be placed within the frame of the picture that she/he paints.' The researcher in this setting is 'not [an] invisible, anonymous, disembodied voice of authority, but ... a real, historical individual with concrete, specific desires and interests - and ones that are sometimes in tension with each other.' See Sandra Harding, 'The Method Question' (1987) 2(3) Hypatia 19, 31, 32.

47 See generally, Upendra Baxi, 'From Human Right to the Right to Be Human: Some Heresies' in Upendra Baxi (ed), The Right to be Human (Lancer International 1987).
} 